\title{
PEAK PLANTAR PRESSURE AS A RISK FACTOR FOR LOWER EXTREMITY OVERUSE INJURY AMONG INFANTRY SOLDIERS
}

\author{
Darja N̦esteroviča ${ }^{1, \#}$, Ainārs Stepens ${ }^{1}$, and Normunds Vaivads ${ }^{2}$ \\ ${ }^{1}$ Military Medicine Research and Study Centre, Rīga Stradinš̌ University, 14 Baložu Str., Rīga, LV-1048, LATVIA \\ 2 Joint Medical Service Headquarters, National Armed Forces, LATVIA \\ \# Corresponding author, darja.nesterovica@rsu.lv
}

Communicated by Modra Murovska

The majority of reported injuries among military populations are injuries due to cumulative repetitive microtrauma - overuse injuries. Plantar pressure measurement is a simple tool to analyse lower limb biomechanics through the assessment of forces applied to the foot. This study aimed to determine the relation between peak plantar pressure and lower extremity overuse. Sixty-six active-duty infantry male soldiers, with mean age 29.7 years (range 22-40 years), and mean service time 5.2 years (range 1-15 years) participated. The highest peak plantar pressure (PPP) at the forefoot occurred at the hallux (cases: $50.82 \mathrm{n} / \mathrm{cm}^{2}, S D=38.84$; control: $34.39 \mathrm{n} / \mathrm{cm}^{2}, S D=$ 28.03) and $3^{\text {rd }}$ metatarsal head (cases: $54.40 \mathrm{n} / \mathrm{cm}^{2}, S D=33.83$; control: $49.16 \mathrm{n} / \mathrm{cm}^{2}, S D=$ 28.87). The study demonstrated elevated PPP among cases. Statistically significant results were found at the hallux $(\chi 2(1)=6.8 ; p=0.01)$, medial heel $(\chi 2(1)=5.18 ; p=0.02)$ and lateral heel $(\chi 2(1)=12.12 ; p<0.01)$ regions. The results show that plantar pressure assessment could be used as a useful screening tool for early lower extremity overuse injury detection.

Key words: military personnel, cumulative trauma disorder, baropodometry.

\section{INTRODUCTION}

Sustaining an injury reduces military readiness, increases the financial burden of additional health care and is a leading cause of medical discharge among military personnel (Geary et al., 2002; Jones et al., 2010; Ruscio et al., 2010; Lovalekar et al., 2018). Musculoskeletal injuries (MSKI) are common among different countries and the reported injury rates are consistently high. Reported acute and overuse injury incidence in the British army is $49 \%$ and it is 53\% for military personnel in the USA (Sharma et al., 2015; Grier et al., 2020). The majority of reported MSKI among different military populations are injuries due to cumulative repetitive microtrauma (Hoffman et al., 2015). Repetitive highintensity training with a short recovery period is a significant contributor to injury with gradual onset - overuse injury (Kaufman et al., 2000). For example, it has been reported that $51 \%$ of young conscripts in Finland during six months sustained an overuse injury (Taanila et al., 2015).

Previous studies showed that a history of injury is a strong risk factor for the next injury (Knapik et al., 2003; Fulton et al., 2014). For this reason, systematic injury rate assessment and long-term injury trend monitoring are important parts of the injury prevention process (Wardle and Greeves, 2017). Regional Logistics Command (LC) military medical care centres in Latvia provide written acute musculoskeletal injury monthly reports to the National Armed Forces LC Military Medical Support Centre. Medical reports contain data on the injured person, injury date and place, injured body part and side, and injury type similar to the Barell injury matrix (Barell et al., 2002). Medical-record based on oneyear injury incidence in the Latvian Army is $12.4 \%$; most injured locations are lower legs $(2.5 \%)$, foot and toes $(1.7 \%)$ with only three cases of stress fractures reported.

The Latvian Land Forces are one of the biggest military branches of the Latvian Army, with three thousand soldiers involved at average age 34.2 years. A large portion of the Latvian Army is formed by infantry soldiers, also known as "foot soldiers". According to survey results among infantry soldiers, the lower extremity is the most injured body site $(56 \%)$, where self-reported lower extremity overuse injury 
occurs in $45 \%$ subjects. In comparison, self-reported upper extremity overuse injury occurrence is only $11 \%$ (Nesterovica, 2018).

Foot health for infantry is essential in not only providing adequate shock-absorbing and normal gait cycle on uneven terrain, but also in maintaining good health status and the highest state of military readiness. Foot type as well as forces applied to the foot are important. Studies have shown good Foot Posture Index (FPI) inter- and intra-rater reliability with the ability to quantify foot type (Redmond et al., 2006; Cornwall et al., 2008; Morrison and Ferrari, 2009) . Plantar pressure measurement with a pressure plate is a simple method to assess the direction and force applied to the foot and it is a key tool to analyse lower limb biomechanics (Landorf and Keenan, 2000). For plantar pressure management, foot orthotics with different stiffness and cushioning components have been used among pathological and healthy populations (Bonanno et al., 2019; Chatzistergos et al., 2020). Different foot orthotics have shown good results in lower limb injury incidence reduction during military training (Snyder et al., 2009; Bonanno et al., 2018).

Limited evidence regarding plantar pressure values and injury risk exists. Few studies previously investigated peak plantar pressure among injured and healthy Royal Marines recruits and young Navy officers. High arch and greater peak plantar pressure at the medial side of the foot increased risk for a metatarsal stress fracture and ankle inversion injury among Royal Marines; Dixon et al., 2019). Plantar pressure has been reported to be a predictive factor of sustaining an overuse injury of the lower limb in a controlled training environment of Navy officers (FranklynMiller et al., 2014).

This study aimed to investigate the relation between peak plantar pressure and lower extremity overuse injuries among Latvian infantry soldiers.

\section{MATERIALS AND METHODS}

Subjects. Sixty-six active-duty infantry soldiers participated in the case-control study, all were males at mean age 29.7 years (range 22-40 years) and with mean service time 5.2 years (range $1-15$ years). Cases were soldiers with prior lower leg (knee, ankle, or foot) overuse injury during the last six month period (cases); persons who did not sustain any lower extremity injury during the same period were the control group). Overuse injury was defined as MSKI caused by repetitive and/or forceful tasks or appeared as a result of repeated overstretching or overloading (Cheron and Scanff, 2016). Overuse lower limb injuries included in this definition were: plantar fasciitis, metatarsalgia, Achilles tendinopathy, stress fracture, medial tibial stress, patellofemoral syndrome, chronic exertional compartment syndrome, and iliotibial band syndrome.

Information about injuries was obtained from surveys during the annual medical check-up and from medical record data. During the data collection period, all of the participants were not injured and were free of any musculoskeletal pain. Participation was voluntary and all study subjects provided written informed consent. Ethical approval was obtained from the Ethics Committee of Rīga Stradiņ̌̌ University (No. 40/26.10.2017).

Procedure and data extraction. A pressure platform $(2 \mathrm{~m} \times 0.4 \mathrm{~m} \times 0.02 \mathrm{~m}$, RSscan International, Belgium) was embedded in the centre of a 5-metre long walkway. Firstly, weight calibration was performed. Participants were asked to walk barefoot in a relaxed manner at a self-selected comfort speed, and not to look at the ground. To minimise walking speed influence on plantar pressure measurement, a two-step initiation protocol was used, such that participants were positioned two steps from the platform edge. Two walking trials were used for acclimatisation; mean data from three successful trials were analysed for each foot.

Plantar pressure analysis software (Footscan v.7.11, RSscan International) was configured to measure plantar pressures in $\mathrm{n} / \mathrm{cm}^{2}$. Software masks the foot into 10 regions: hallux, lesser toes, each metatarsal head (1st MTH, 2nd MTH, 3rd MTH, 4th MTH, and 5th MTH), midfoot, heel medial and heel lateral. Peak plantar pressure (PPP) values, contact area, and foot length values were extracted. The degree of plantar pressure asymmetry for each region was determined between the left and right foot in both groups using the symmetry index (Robinson et al., 1987; Wafai et al., 2015). A value of 0 indicates perfect symmetry between feet plantar loading, while a higher value indicates higher asymmetry in plantar loading.

For FPI measurement, the subjects were asked to stand in a relaxed stance position with double-limb support, arms relaxed and looking straight forward. Additionally, foot arch types were classified based on arch index (AI) measurement. Three categories were used based on values in previous studies: high-arch $(\mathrm{AI} \leq 0.21)$, normal arch $(0.22<\mathrm{AI} \leq$ 0.26), low arch (AI > 0.27) (Cavanagh and Rodgers, 1987; Hernandez et al., 2007). All measurements were made by the same examiner.

Data analysis. Statistical analyses were performed using the SPSS 22.0 software package. Firstly, all data were assessed for normality using the Shapiro-Wilk test. Mostly, data were not normally distributed; nonparametric tests were applied in order to determine differences between groups. Data are presented as means with standard deviation if not stated otherwise. The Mann-Whitney test was used to determine SI differences among groups. The significance level was set to $p<0.05$ (two-tailed).

\section{RESULTS}

In total, 32 subjects were included in the case group and 34 subjects were included in the control group. Case and control group characteristics are shown in Table 1. Both group demographic characteristics as well as foot posture vari- 
Table 1. Characteristics of study participants

\begin{tabular}{|c|c|c|c|}
\hline & $\begin{array}{l}\text { Cases, } \\
\mathrm{n}=32\end{array}$ & $\begin{array}{c}\text { Controls, } \\
\mathrm{n}=34\end{array}$ & $\begin{array}{c}p \\
\text { value }^{\mathrm{a}}\end{array}$ \\
\hline Age, years & $28.5(5.2)^{b}$ & $30.24(5.4)$ & 0.07 \\
\hline Height, m & $1.81(0.08)$ & $1.77(0.07)$ & 0.93 \\
\hline Weight, $\mathrm{kg}$ & $80.5(12.6)$ & $81.1(12.6)$ & 0.93 \\
\hline BMI, $\mathrm{kg} / \mathrm{m}^{2}$ & $24.6(2.7)$ & $25.7(2.3)$ & 0.05 \\
\hline Footprint length, mm & $275(1.26)$ & $273(1.28)$ & 0.15 \\
\hline \multirow[t]{2}{*}{ Self-selected military boot size } & $43.5(1.6)$ & $42.8(1.4)$ & 0.04 \\
\hline & \multicolumn{2}{|c|}{ Smoking status, $\mathrm{n}$} & 0.83 \\
\hline Non-smokers & $\mathrm{n}=18$ & $\mathrm{n}=20$ & \\
\hline \multirow[t]{2}{*}{ Smokers } & $\mathrm{n}=14$ & $\mathrm{n}=14$ & \\
\hline & \multicolumn{2}{|c|}{ Physical activity, hours/week, n } & 0.59 \\
\hline $1-2$ & $\mathrm{n}=9$ & $\mathrm{n}=9$ & \\
\hline $3-4$ & $\mathrm{n}=18$ & $\mathrm{n}=17$ & \\
\hline \multirow[t]{2}{*}{$5 \mathrm{fs} 22$} & $\mathrm{n}=5$ & $\mathrm{n}=8$ & \\
\hline & \multicolumn{2}{|c|}{ Left foot position, $\mathrm{n}$} & 0.70 \\
\hline Supinated foot & $\mathrm{n}=6$ & $\mathrm{n}=2$ & \\
\hline Neutral foot & $\mathrm{n}=19$ & $\mathrm{n}=25$ & \\
\hline Pronated foot & $\mathrm{n}=7$ & $\mathrm{n}=7$ & \\
\hline \multirow[t]{2}{*}{ Arch index } & $0.26(0.06)$ & $0.26(0.08)$ & 0.60 \\
\hline & \multicolumn{2}{|c|}{ Right foot position, $\mathrm{n}$} & 0.70 \\
\hline Supinated foot & $\mathrm{n}=4$ & $\mathrm{n}=1$ & \\
\hline Neutral foot & $\mathrm{n}=25$ & $\mathrm{n}=27$ & \\
\hline Pronated foot & $\mathrm{n}=3$ & $\mathrm{n}=6$ & \\
\hline Arch index & $0.26(0.07)$ & $0.26(0.7)$ & 0.60 \\
\hline
\end{tabular}

${ }^{\mathrm{a}} p$ values based on Mann-Whitney test; ${ }^{\mathrm{b}}$ standard deviation is given in parentheses; foot posture determined using the Foot Posture index; significant results are marked in bold.

ables did not differ significantly between the groups. Mean footprint length did not differ, although smaller self-selected shoe sizes were observed among controls and mean self-selected shoe size difference observed between groups was statistically significant.

Foot types according to AI among case and control groups did not differ significantly; the foot arch was classified as normal $(\mathrm{AI}=0.26)$. The total FPI score ranged from -5 to 10 (median 3.00) for both groups. Pronated $(n=7)$ and supinated $(n=6)$ left foot posture among cases were more frequent. FPI values between the left and right foot as well as between groups did not differ significantly $(\chi 2(1)=0.15$, $p=0.70)$. However, the supinated foot position was a more common condition among cases.

Plantar pressure assessment showed differences between groups. See Figure 1 for PPP distribution among forefoot, midfoot, and rearfoot. Cases showed higher PPP in the forefoot and rearfoot regions. Highest PPP at the forefoot was shown at the hallux $\left(49.85 \mathrm{n} / \mathrm{cm}^{2}, \mathrm{SD}=40.26\right)$ and $3^{\text {rd }}$ metatarsal head $(50.38 \mathrm{n} / \mathrm{cm} 2, \mathrm{SD}=38.53)$. At the rearfoot, highest PPP were at both heel regions medial and lateral, $55.26 \mathrm{n} / \mathrm{cm} 2(\mathrm{SD}=37.31)$, and $58.2 \mathrm{n} / \mathrm{cm}^{2}(\mathrm{SD}=34.94)$, respectively. Both groups showed similar PPP values in the

\section{Peak plantar pressure, $\mathrm{N} / \mathrm{cm}^{2}$}
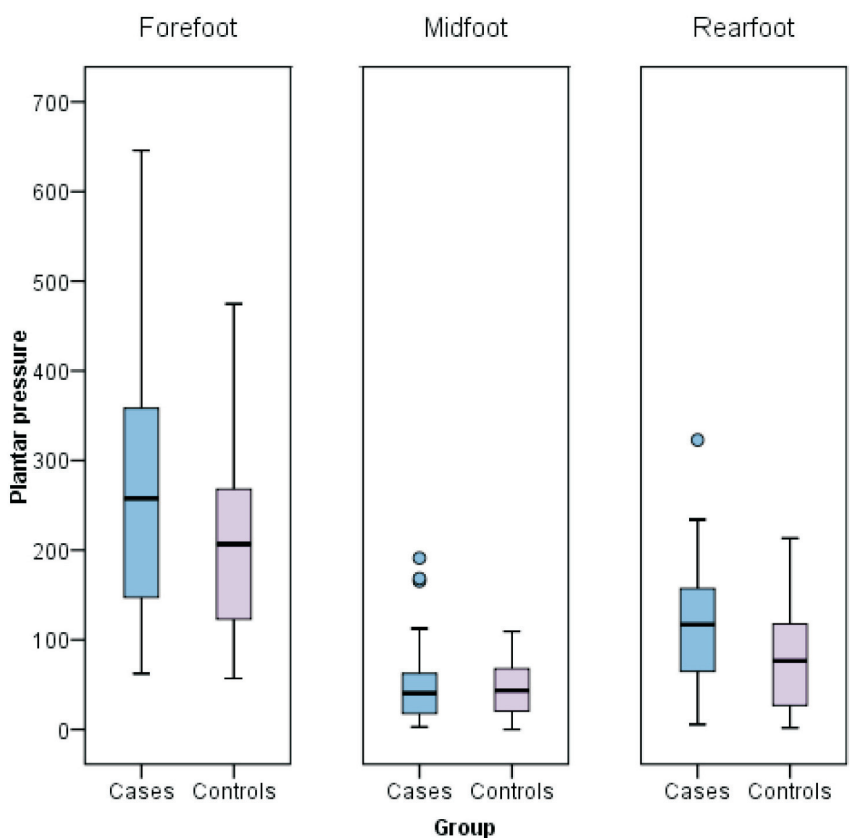

Fig. 1. Peak plantar pressure distribution during barefoot walking among study groups for different foot regions. Peak plantar pressure observed in the cases group shows wide variation, higher values were observed in the forefoot region.

midfoot region. Highest PPP among the control group was found under the 3rd metatarsal head $\left(45.43 \mathrm{n} / \mathrm{cm}^{2}, \mathrm{SD}=\right.$ 28.12). In spite of the fact that PPP was greater among cases, when compared with controls the differences were not statistically significant except for hallux $(\chi 2(1)=6.8$; $p=0.01)$ and for medial $(\chi 2(1)=5.18 ; p=0.02)$ and lateral $(\chi 2(1)=12.12 ; p<0.01)$ heel regions. Table 2 shows peak plantar pressure values for the different zones of the foot among groups.

Table 3 illustrates the median PPP asymmetry among study groups. The degree of plantar pressure asymmetry according to SI in the case group showed a median range between $1-45 \%$ across different foot regions; perfect symmetry was found under the $5^{\text {th }}$ MTH and medial heel. SI values were lower for the control group, with detected levels of asymmetry range between $\sim 7 \%$ to $16 \%$, and perfect symmetry found under lesser toes, $3^{\text {rd }}$ and $5^{\text {th }}$ MTH. A statistically significant SI difference between groups was found under the $1^{\text {st }}$ MTH.

\section{DISCUSSION}

The vast majority of injuries in the physically active population, as well as military populations, are MSKI, and most are MSKI of lower extremities due to overuse (Hauschild et al., 2019). Lower extremity and especially foot health is crucial for military readiness of infantry soldiers. The present study assessed foot health using FPI, PPP data, and footwear comfort ratings among infantry soldiers with and without a history of lower extremity overuse injury. 
Table 2. Peak plantar pressure values among cases and controls for each foot, $\mathrm{n} / \mathrm{cm} 2$, (SD)

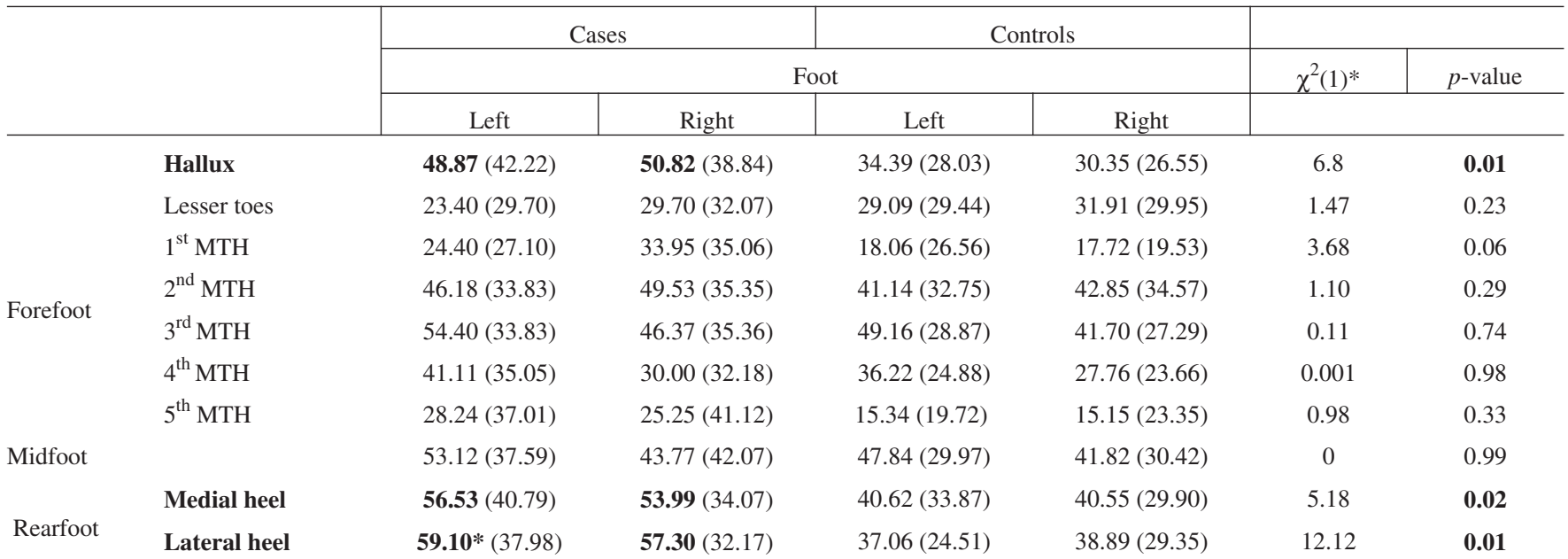

*Kruskal Wallis test results; SD, standard deviation; MTH, Metatarsal head; significant results are marked in bold; differences relate to both left and right feet.

Table 3. Median peak plantar pressure assymetry percentage in case and control groups with standard deviation

\begin{tabular}{l|cc|c}
\hline & Cases & Controls & \multirow{2}{*}{$p$-value } \\
\cline { 2 - 3 } & \multicolumn{2}{|c}{ Median assymetry, \% } & 0.40 \\
Hallux & $-45.95(67.87)$ & $-16.44(63.70)$ & 0.12 \\
Lesser toes & $9.52(96.26)$ & $0.00(54.53)$ & $\mathbf{0 . 0 2}$ \\
1st MTH & $\mathbf{2 2 . 2 2 ( 9 1 . 2 3 )}$ & $\mathbf{0 . 0 0 ( 4 7 . 5 5 )}$ & 0.25 \\
2nd MTH & $16.80(54.67)$ & $13.12(58.48)$ & 0.51 \\
3rd MTH & $-3.60(50.54)$ & $-16.81(59.80)$ & 0.11 \\
4th MTH & $-23.52(71.60)$ & $-15.34(40.37)$ & 0.95 \\
5th MTH & $0.00(72.86)$ & $0.00(34.41)$ & 0.22 \\
Midfoot & $-29.37(62.37)$ & $-8.97(57.36)$ & 0.53 \\
Medial heel & $0.00(57.91)$ & $13.65(36.09)$ & 0.81 \\
Lateral heel & $-1.76(54.24)$ & $7.82(55.41)$ &
\end{tabular}

Mann-Whitney test results; a negative value indicates higher pressure at the left foot; standard deviation is given in brackets; MTH, metatarsal head; significant results are marked in bold.

Plantar pressure measurements are very useful for foot function assessment, but generalised assumptions based only on levels of PPP cannot be made. Plantar pressures vary widely among individuals and there is no single plantar pressure value that can be used as an indicator for the onset of a foot injury (Wafai et al., 2015). Our study data indicated that statistically significant PPP differences between cases and control groups exist at the hallux and heel regions, which correspond to heel-contact and toe-off gait cycle phases. It has been reported that for a healthy foot, larger motion in the foot joints during walking was associated with lower plantar pressure in almost all regions (Giacomozzi et al., 2014). It is recommended to investigate gait pattern as well as foot and ankle motion to establish a possible association with lower extremity injury.

Scoring of foot type with the FPI-6 was not significantly associated with a history of previous lower extremity overuse injury. Despite that, cases appeared to have a non-neutral foot position more frequently when compared with controls. This finding is consistent with a previous study, where lower extremity overuse injury was linked with a nonneutral foot position (Yates and White, 2004).

Our findings showed asymmetry in both FPI and PPP among cases and controls. Foot posture and function can be affected by injuries. The site of injury is often reflected not only in the plantar pressure distribution but also in the measures of asymmetry between the feet (Wafai et al., 2013). SI was used for plantar pressure symmetry assessment. The normal range of asymmetry determined among healthy individuals is approximately 10-18\% (Wafai et al., 2015), which is similar to SI values found in our control group (SI values from $0 \%$ to $16 \%$ ). Larger and statistically significant PPP asymmetry between cases and controls was found at the $1^{\text {st }} \mathrm{MTH}$. The presence of asymmetry between feet means unequal lower limb loading and imbalance during walking, which requires the attention of physiotherapists. However, lower limb motion during the gait cycle has been considered as globally symmetrical (Sadeghi, 2003). Lower limb dominance is task-dependent and it can impact the roles the lower limbs play during the gait cycle and contribute to a local asymmetry. Improving the abnormal biomechanical parameters of the lower extremity during military training can prevent stress fracture of the lower limbs (Zhao et al., 2020).

Infantry soldier's feet are regularly exposed to large forces and are constantly adapting to various environments. Footwear should be comfortable to reduce pressure, shear, and shock forces from the foot. Consequently, it is important to analyse foot function as well as military footwear comfort and proper fit. Footwear sizes in the Latvian Army have been self-selected by the soldier and an improper size may have been used. It is known that a large proportion of the common population wear incorrectly sized footwear, which is associated with foot pain and foot disorder (Schwarzkopf et al., 2011; Buldt and Menz, 2018). Our study identified that cases used bigger shoe sizes than controls $(p=0.04)$, 
but the difference between groups was not statistically significant. Such a difference might appear due to different foot width or lack of footwear comfort among injured subjects and these factors were not included in data analysis.

Our study findings should be considered in context with limitations of the study. The retrospective case-control study design was a limitation due to the relatively small study population, inability to establish causal sequences, and recall bias of history of injury. The study grouping also depended on medical-record quality. It has been reported that approximately half of MSKI among infantry populations are not reported to medical personnel (Smith et al., 2016). The used plantar pressure system is able to measure the force that is perpendicular to the pressure sensor and it is not possible to measure other forces, for example, shear forces. The masking process was performed automatically by the software, which could shift plantar pressure values. It has been reported that automated masking reduces overall pressure values (Deschamps et al., 2009). Gait kinematic and EMG data were not collected and therefore conclusions about overall lower limb biomechanics and their influence on injury risk could not be made.

\section{CONCLUSIONS}

To the authors' knowledge, this is the first study of peak plantar pressure and symmetry index among infantry soldiers in Latvia with and without a history of lower extremity overuse injury. The study results demonstrate elevated peak plantar pressures among cases with prior lower extremity injury. Significantly high results were found at forefoot (hallux, $\chi^{2}(1)=6.8 ; p=0.01$ ) and rearfoot (medial heel $\left(\chi^{2}(1)=5.18 ; p=0.02\right.$; lateral heel $\left(\chi^{2}(1)=12.12 ; p<\right.$ $0.01)$ ). Cases demonstrated asymmetrical peak plantar pressures and foot posture. The results showed that plantar pressure assessments could be a useful screening tool for early lower extremity overuse injury detection or in planning implementation of an injury prevention programme.

\section{ACKNOWLEDGEMENTS}

The author would like to thank soldiers who participated in the study and Latvian National Armed Forces LC Military medical support centre for the support.

\section{REFERENCES}

Barell, V., Aharonson-Daniel, L., Fingerhut, L. A., Mackenzie, E. J., Ziv, A., Boyko, V., Abargel, A., Avitzour, M., Heruti, R. (2002). An introduction to the Barell body region by nature of injury diagnosis matrix. Injury Prev., 8 (2), 91-96

Bonanno, D. R., Ledchumanasarma, K., Landorf, K. B., Munteanu, S. E., Murley, G. S., Menz, H. B. (2019). Effects of a contoured foot orthosis and flat insole on plantar pressure and tibial acceleration while walking in defence boots. Sci. Rep. 9 (1), 1-10.

Bonanno, D. R., Murley, G. S., Munteanu, S. E., Landorf, K. B., Menz, H. B. (2018). Effectiveness of foot orthoses for the prevention of lower limb overuse injuries in naval recruits: a randomised controlled trial. Brit. J. Sports Med., 52 (5), 298-302.
Buldt, A. K., Menz, H. B. (2018). Incorrectly fitted footwear, foot pain and foot disorders: A systematic search and narrative review of the literature. $J$. Foot Ankle Res., 11, 43.

Cavanagh, P. R., Rodgers, M. M. (1987). The arch index: A useful measure from footprints. J. Biomech., 20 (5), 547-551.

Chatzistergos, P. E., Gatt, A., Formosa, C., Farrugia, K., Chockalingam, N. (2020). Optimised cushioning in diabetic footwear can significantly enhance their capacity to reduce plantar pressure. Gait Posture, 79, 255-250.

Cheron, C., Scanff, C., Le Leboeuf-Yde, C. (2016). Association between sports type and overuse injuries of extremities in children and adolescents: A systematic review. Chiropractic Manual Ther., 24, 41

Cornwall, M. W., McPoil, T. G., Lebec, M., Vicenzino, B., Wilson, J. (2008), Reliability of the modified foot posture index. J. Amer. Podiatric Med. Assoc., 98 (1), 7-13.

Deschamps, K., Birch, I., Mc Innes, J., Desloovere, K., Matricali, G. A. (2009). Inter- and intra-observer reliability of masking in plantar pressure measurement analysis. Gait Posture, 30 (3), 379-382.

Dixon, S., Nunns, M., House, C., Rice, H., Mostazir, M., Stiles, V., Davey, T., Fallowfield, J., Allsopp, A. (2019). Prospective study of biomechanical risk factors for second and third metatarsal stress fractures in military recruits. J. Sci. Med. Sport, 22 (2), 135-139.

Franklyn-Miller, A., Bilzon, J., Wilson, C., McCrory, P. (2014). Can RSScan footscan ${ }^{\circledR} \mathrm{D} 3 \mathrm{D}^{\mathrm{TM}}$ software predict injury in a military population following plantar pressure assessment? A prospective cohort study. Foot, 24 (1), 6-10.

Fulton, J., Wright, K., Kelly, M., Zebrosky, B., Zanis, M., Drvol, C., Butler, R. (2014). Injury risk is altered by previous injury: A systematic review of the literature and presentation of causative neuromuscular factors. Int. J. Sports Phys. Ther., 9 (5), 583-595.

Geary, K. G., Irvine, D., Croft, A. M. (2002). Does military service damage females? An analysis of medical discharge data in the British armed forces. Occup. Med., 52 (2), 85-90.

Giacomozzi, C., Leardini, A., Caravaggi, P. (2014). Correlates between kinematics and baropodometric measurements for an integrated in-vivo assessment of the segmental foot function in gait. J. Biomech., 47 (11), 2654-2659.

Grier, T., Dinkeloo, E., Reynolds, M., Jones, B. H. (2020). Sleep duration and musculoskeletal injury incidence in physically active men and women: A study of U.S. Army Special Operation Forces soldiers. Sleep Health, 6 (3), 344-349.

Hauschild, V. D., Schuh-Renner, A., Lee, T., Richardson, M. D., Hauret, K., Jones, B. H. (2019). Using causal energy categories to report the distribution of injuries in an active population: An approach used by the U.S. Army. J. Sci. Med. Sport, 22 (9), 997-1003.

Hernandez, A. J., Kimura, L. K., Laraya, M. H. F., Fivaro, E. (2007). Calculation of staheli's plantar arch index and prevalence of flat feet: A study with 100 children aged 5-9 years. Acta Ortopedica Brasileira, 15 (2). Available from: https://doi.org/10.1590/S1413-78522007000200001 (accessed 3 February 2021).

Hoffman, J. R., Church, D. D., Hoffman, M. W. (2015). Overuse injuries in military personnel. In: The Mechanobiology and Mechanophysiology of Military-Related Injuries. Springer, pp. 141-161.

Jones, B. H., Canham-Chervak, M., Sleet, D. A. (2010). An evidence-based public health approach to injury priorities and prevention: Recommendations for the U.S. Military. Amer. J. Prevent. Med., 38 (1 Suppl.), S1-S10.

Kaufman, K. R., Brodine, S., Shaffer, R. (2000). Military training-related injuries: Surveillance, research, and prevention. Amer. J. Prevent.Med.,18 (3 Suppl.), 54-63.

Knapik, J. J., Hauret, K. G., Arnold, S., Canham-Chervak, M., Mansfield, A. J., Hoedebecke, E. L., McMillian, D. (2003). Injury and fitness outcomes during implementation of physical readiness training. Int. J. Sports Med., 24 (5), 372-381.

Landorf, K. B., Keenan, A. M. (2000). Efficacy of foot orthoses. What does the literature tell us? J. Amer. Podiatric Med. Assoc., 90 (3), 149-158. 
Lovalekar, M., Johnson, C. D., Eagle, S., Wohleber, M. F., Keenan, K. A., Beals, K., Nindl, B. C., Connaboy, C. (2018). Epidemiology of musculoskeletal injuries among US Air Force Special Tactics Operators: An economic cost perspective. BMJ Open Sport Exerc. Med., 4 (1), 1-7.

Morrison, S. C., Ferrari, J. (2009). Inter-rater reliability of the Foot Posture Index (FPI-6) in the assessment of the paediatric foot. J. Foot Ankle Res., 2 , 26.

Nesterovica, D. (2018). Musculoskeletal overuse injury prevalence and comfort perception of military boots. In: Proceedings of the 60th International Scientific Conference of Daugavpils University, pp. 123-128. Available from:

https://www.researchgate.net/publication/325966715_Musculoskeletal_ overuse_injury_prevalence_and_comfort_perception_of_military_boots (accessed 3 February 2021).

Redmond, A. C., Crosbie, J., Ouvrier, R. A. (2006). Development and validation of a novel rating system for scoring standing foot posture: The Foot Posture Index. Clin. Biomech., 21 (1), 89-98.

Rice, H., Nunns, M., House, C., Fallowfield, J., Allsopp, A., Dixon, S. (2013). High medial plantar pressures during barefoot running are associated with increased risk of ankle inversion injury in Royal Marine recruits. Gait Posture, 38 (4), 614-618.

Robinson, R. O., Herzog, W., Nigg, B. M. (1987). Use of force platform variables to quantify the effects of chiropractic manipulation on gait symmetry. J. Manipulat. Physiol. Ther., 10 (4), 172-176.

Ruscio, B. A., Jones, B. H., Bullock, S. H., Burnham, B. R., CanhamChervak, M., Rennix, C. P., Wells, T. S., Smith, J. W. (2010). A process to identify military injury prevention priorities based on injury type and limited duty days. Amer. J. Prevent. Med., 38 (1 Suppl), S19-S33.

Sadeghi, H. (2003). Local or global asymmetry in gait of people without impairments. Gait Posture, 17 (3), 197-204.

Schwarzkopf, R., Perretta, D. J., Russell, T. A., Sheskier, S. C. (2011). Foot and shoe size mismatch in three different New York city populations. $J$. Foot Ankle Surgery, 50 (4), 391-394.
Sharma, J., Greeves, J. P., Byers, M., Bennett, A. N., Spears, I. R. (2015). Musculoskeletal injuries in British Army recruits: A prospective study of diagnosis-specific incidence and rehabilitation times Epidemiology of musculoskeletal disorders. BMC Musculoskel. Disord., 16, 106.

Smith, L., Westrick, R., Sauers, S., Cooper, A., Scofield, D., Claro, P., Warr, B. (2016). Underreporting of musculoskeletal injuries in the US Army: Findings from an Infantry Brigade Combat Team survey study. Sports Health, 8 (6), 507-513.

Snyder, R. A., DeAngelis, J. P., Koester, M. C., Spindler, K. P., Dunn, W. R. (2009). Does shoe insole modification prevent stress fractures? A systematic review. HSS J. (Musculoskeletal Journal of Hospital for Special Surgery), 5 (2), 92-98.

Taanila, H., Suni, J. H., Kannus, P., Pihlajamäki, H., Ruohola, J.-P., Viskari, J., Parkkari, J. (2015). Risk factors of acute and overuse musculoskeletal injuries among young conscripts: A population-based cohort study. BMC Musculoskel. Disord., 16, 104

Wafai, L., Zayegh, A., Begg, R., Woulfe, J. (2013). Asymmetry detection during pathological gait using a plantar pressure sensing system. In: Proceedings of the 7th IEEE GCC Conference and Exhibition, GCC 2013 17-20 November 2013. IEEE, Doha, pp. 182-187.

Wafai, L., Zayegh, A., Woulfe, J., Mahfuzul, S., Begg, R. (2015). Identification of foot pathologies based on plantar pressure asymmetry. Sensors, 15 (8), 20392-203408.

Wardle, S. L., Greeves, J. P. (2017). Mitigating the risk of musculoskeletal injury: A systematic review of the most effective injury prevention strategies for military personnel. J. Sci. Med. Sport, 20, S3-S10.

Yates, B., White, S. (2004). The incidence and risk factors in the development of medial tibial stress syndrome among naval recruits. Amer. J. Sports Med., 32 (3), 772-780

Zhao, Y., Zhang, Z., Luo, D., Li, M., Wang, J., Fang, J., Jiang, W., Feng, Y., Peng, J., Xu, W., Wang, Y., Wang, A., Zhang, M. (2020). Risk factors for stress fracture of lower limbs and future research direction. Chinese J. Tissue Eng. Res., 24 (9), 1422-1429.

\section{MAKSIMĀLAIS PLANTĀRAIS SPIEDIENS KĀ APAKŠĒJO EKSTREMITĀŠU PĀRSLODZES TRAUMU RISKA FAKTORS KĀJNIEKU VIDŪ}

Karavīru populācijā liels īpatsvars no novērotām muskuloskeletālām traumām ir kumulatīva rakstura pārslodzes traumas, kas skar apakšējās ekstremitātes. Pēdas plantāro spiedienu jeb uz pēdām izdarītā spēka sadalījuma izmeklēšana ir vienkārša apakšējo ekstremitāšu biomehānikas analīzes metode. Šis pētījums analizē saistību starp maksimālo plantāro spiedienu (MPS) un apakšējo ekstremitāšu pārslodzes traumām. Gadījumu-kontroles pētījumā piedalījās sešdesmit seši aktīvā dienesta kājnieki, vidējais vecums 29,7 gadi (vecuma diapazons 22-40 gadi); vidējais izdienas ilgums 5,2 gadi (no 1 līdz 15 gadiem). MPS pēdas priekšējā daļā tika reǵistrēts I pirksta rajonā (gadījumi: $50,82 \mathrm{n} / \mathrm{cm}^{2}, \mathrm{SD}=38,84$; kontroles: $34,39 \mathrm{n} / \mathrm{cm}^{2}, \mathrm{SD}=28,03$ ) un pie III pleznas kaula (gadījumi: $54,40 \mathrm{n} / \mathrm{cm}^{2}, \mathrm{SD}=33,83$; kontroles: $\left.49,16 \mathrm{n} / \mathrm{cm}^{2}, \mathrm{SD}=28,87\right)$. Paaugstināti MPS tika novēroti gadījumu grupā. Statistiski ticamas atškirības atrastas pie I pirksta $\left(\chi^{2}(1)=6,8\right.$; $p=0,01)$, papēža rajonā mediāli $\left(\chi^{2}(1)=5,18 ; p=0,02\right)$ un laterāli $\left.\chi^{2}(1)=12,12 ; p<0,01\right)$. Pētījuma rezultāti rāda, ka pēdu plantārā spiediena izmeklēšana ir noderīga skrīninga metode agrīnai apakšējo ekstremitāšu pārslodzes traumu diagnostikai. 